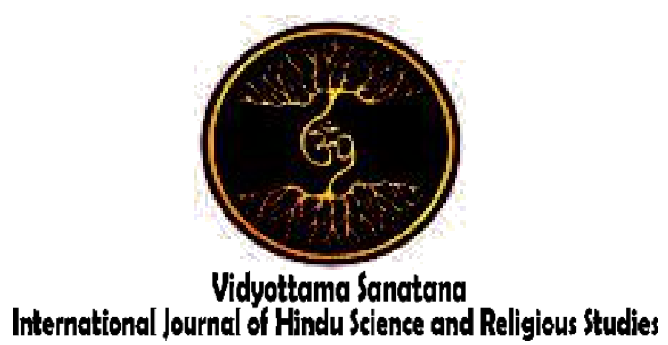

Vol. 3 No. 1 May 2019

\title{
THE MYSTISIM OF BHAIRAWA TANTRA IN THE MYTH OF IDA RATU GEDE MAS MACALING DALEM NUSA IN THE BALINESE CULTURAL TRADITION
}

\author{
By: \\ I Made Dian Saputra \\ Institut Hindu Dharma Negeri Denpasar \\ E-mail : dektonk85@yahoo.com
}

\begin{tabular}{|c|c|}
\hline Received: January 14, 2019 & Accepted: May 21, 2019 \\
\hline
\end{tabular}

\begin{abstract}
The myth of Ida Ratu Gede Mas Macaling Dalem Nusa still exists until now. The myth is so alive in the Balinese social environment that it is made to be identical with everything which is mysterious. Its existence is always connected with the practice of native healing and other growing and developing traditional spiritual practices. There are several palm-leaf manuscripts narrating the existence of Ida Ratu Gede Mas Macaling Dalem Nusa. The version narrated in one palm-leaf manuscript is different from that narrated in another. However, his existence is always connected with the existence of one small island named Nusa Penida, an island which is under his control. He is pictured as a "frightening" spirit and the myth and his existence have hypnotized the Balinese people; therefore, it is interesting to investigate the myth. The existence of the myth is described from the perspective of the mysticism of Bhairawa Tantra, which developed rapidly during its era in Bali.
\end{abstract}

Keywords: Mysticism of Bhairawa Tantra, Myth of Ida Ratu Gede Mas Macaling

\section{Introduction}

The myth of Ida Ratu Gede Mas Macaling Dalem Nusa Penida is a myth which refers to what is narrated in the palmleaf manuscript of "Nusa Penida" (the version written by Jero Mangku Made Buda, 2008: 9). It is identical with what is narrated in the palm-leaf manuscript "Lontar Dukuh Jumpungan" (the version which Gedong Kertya has, 1976), in which it is genealogically narrated that the character Ratu Gede Macaling is a common human being, the son of I Renggan and $\mathrm{Ni}$ Merahim. I Gede Macaling was born in 180 
Caka year, and his sister named Ni Tole was born in 185 Caka year. Ni Tole was married to Dalem Sawang, the king of Nusa.

Further, it is narrated in the chronicle that I Gede Macaling could perfectly did the activity of ' $t a p a$ ' for which Lord Rudra ' 'Ida Bhatara Rudra' rewarded him what is referred to as 'Panca Taksu', namely the five strengths which everybody can have, causing him to be named Ida Ratu Gede Mas Macaling Dalem Nusa Penida with the power of Panca Taksu ${ }^{3}$. It is this which has caused him to have the mystical image for those who are interested in spirituality and the other practitioners of mysticism.

It is interesting to analyze the myth narrated in the chronicle from the paradigm of the mysticism of highly influential Bhairawa Tantra when Kebo Paru came from Kediri (Redig, 2009: 430). It was in that era Bhairawa Tantra was highly influential and was referred to as the spirit of the practices of diversity in Bali. It is possible that such a teaching has contributed to the myth of Ida Ratu Gede Mas Macaling and the other myths of the same type. In relation to that, it is interesting to explore this myth from what is taught in Bhairawa Tantra as discussed below.

\section{Methods}

The myth of Ida Ratu Gede Mas Mecaling cannot be separated from ideas and concepts. According to Saussure (in Sutrisno, 2005:115), language is made up of the acoustic image (word and sound) which cannot be separated from concepts or ideas. Based on that, the myth of Ida Ratu Gede Mas Macaling is a language containing the sign system involved in the complex signifying process. Therefore, the myth of Ida Ratu Gede Mas Mecaling Dalem Nusa is a set of what is signified composed in a structure (Sutrisna, 2005:115). As a set of what is signified composed in a structure, the myth Ida Ratu Gede Mas Mecaling Dalem Nusa cannot be mystically separated from Tantra Bhairawa.

Based on what was described above, the myth of Ida Ratu Gede Mas Macaling
Dalem Nusa is something which is signified and strengthens the supernatural life of the Balinese society and the existence of the Balinese culture. Therefore, every spirit, social life and mystery is directly connected with the existence of the myth of Ida Ratu Gede Mas Macaling Dalem Nusa. The social elements which directly touch the magical and mysterious aspects of the Balinese society directly function to strengthen supernaturalism which can be discussed as follows.

\section{Results And Discussion}

The Mysticism of Bhairawa Tantra in the Myth of Ida Ratu Gede Mas Macaling Dalem Nusa

The stories in the past about gods, ancestors and other mysterious things in the Balinese civilization have been made to be alive by the mysticism of Bhairawa Tantra. Based on what is stated by Atmaja (2017: 76), the mysticism of Bhairawa cannot be separated from the magical and mysterious things which are connected to events which are not only to be understood but also reflect deep daily meanings. Similarly, the myth of Ida Ratu Gede Mas Macaling Dalem Nusa is strongly connected with the influence of Bhairawa Tantra, as discussed below.

\section{The Unity of Bhairawa-Bhairawi}

Consciously, the myth of Ida Ratu Gede Mas Macaling Dalem Nusa is the actual personification of the transcendent strengths resulting from the unity of the strength of Bhairawa and the strength of Bhairawi. In the teaching of Bhairawa Tantra, it is believed that Bhairawa and Bhairawi are the divine personalities with so many forms and shapes based on their prawerti and niwerti natures (Putrawan, 2008:67; Acri, 2018: 233).

Praweti and niwerti are two dual personalities which are mystically united. Prawerti is the positive nature of Hyang Bhairawa and niwerti is his negative nature for which he is referred to as Bhairawi. In this case, the negative and positive natures are not identical with bad and good natures. 
Textually, they are the unification of two dual things; in other words, they are unification of what are referred to as Purusha and Prakerti. It is this mystical unification which leads to life. The form and shape of these personalities cannot be separated from the supernatural aspect of Hyang Bhairawa-Bhairawi as the controller of the immanent and transcendent strength.

In Bhairawatattawa this strength is referred to Mahasiddha. Literally, Bhairawa shows supernatural power, and Mahasiddha means extraordinary strength and the only strength which controls the world. The only strength which can control the world is the powerful personality. In relation to that, Bhairawa-Bhairawi is not different from Siwa-Sakti from the aspect of krura ${ }^{4}$ (Sukayasa, 2010: 32).

The personification of Ida Ratu Gede Macaling Dalem Nusa also represents the unification of the transcendent strength of the niwerti nature of Hyang Bhairawa with the immanent strength of the prawerti nature of Hyang Bhairawi. It is this unification of strengths which has directly led to the belief that Ida Ratu Gede Macaling Dalem Nusa is a myth that shows a process through which such unification takes place in the magical space, causing the spirit 'taksu' to appear.

Therefore, actually, the existence of the myth of Ida Ratu Gede Mas Mecaling Dalem Nusa, which has developed in the social environment of the Balinese community, represents the ideology of Bhairawa Tantra, which is adjusted to the local belief. The ideological localization has taken place, causing the Bhairwaism to have dominated what is believed by the Hindu society in Bali more strongly.

2. The Unification of Sekala-Niskala (what is visible and what is invisible)

Sekala (what is visible) and niskala (what is invisible) refer to the ways in which the Balinese culture views, inspires and behaves towards a cultural product. Therefore, it can be stated that the culture, which views something from what is visible and invisible, tries to unify the visible side of something and its invisible side, which is believed to exist by the Balinese people. Every culture starts from what is invisible and what is visible at the same time (Tim, 2016: 43).

In so far as the Balinese culture is concerned, the Balinese people believe that there are invisible things which affect them. Such a belief has been a communal one which has been strongly rooted.

In relation to the existence of Ida Ratu Gede Mas Macaling Dalem Nusa Penida, the Balinese people believe in it based on two points of view, namely what is visible (sekala) and what is invisible (niskala). From the niskala (invisible) point of view, there are several metaphysical things which have made the Balinese people believe that the existence of Ida Ratu Gede Mas Macaling Dalem Nusa Penida has affected the form of the ritual tradition performed. That has also affected the physical life of the Balinese people itself, as can be seen from the information obtained through an interview as follows.

"Masyarakat Bali termasuk saya meyakini, ada beberapa saat atau waktu, Ida Ratu Gede Macaling Dalem Nusa, sering berkunjung ke tanah Bali, Mungkin beliau juga membawa banyak ancangan (pengikut). Meskipun hal itu tidak bisa dilihat secara mata telanjang. Namun saya meyakini bahwa hal itu ada, sebab saya sendiri dapat merasakan beberapa hal mengenai hal tersebut (wawancara: Jero Mangku Sunarta, 20 February 2019).

The free translation is as follows:

"The Balinese people, including me, believe that sometime Ida Ratu Gede Macaling Dalem Nusa visits Bali Island. $\mathrm{He}$ is followed by many followers. Although he is invisible, I believe in his existence; the reason is that I can feel that" (the interviewee: 
Jero Mangku Sunarta, 20 February 2019).

The information obtained through the interview above shows that the informant strongly believes that Ida Ratu Gede Mas Macaling Dalem Nusa Penita often comes. Actually, such a belief used to be an individual belief which has changed into a communal one when everybody at a village believes in his existence. Then everybody in one district or even in every part of Bali believes in his existence too. The following information was obtained from another informant.

"Kita melaksanakan upacara memohon keselamatan dari wabah penyakit, dan memohon perlindungan kepada Bhatara (dewata) masingmasing tujuannya adalah untuk melindungi diri dan keluarga. Sebab ketika Ida Ratu Gede Macaling melakukan lunga (perjalanan) menuju Balki, dari tanah Nusa Penida menuju Bali, maka ada banyak sekali rencang (pengikut) yang mengiringi. Biasanya karena beliau adalah penguasa segala macam halangan (Wighnaiswara), maka tentu saja hal positif dan negative yang ditimbulkan. Hal-hal negatif ini bisa berupa penyakit, bencana alam, atau kondisi lingkungan berubah seolah-olah musim hujan, tetapi panas. Upacara diperuntukan menetralisir hal itu" (Wawancara: I Wayan Gede Upadana, 22 February 2019).

The free translation is as follows:

"We perform the ritual to propose to Gods that we and our families be saved and protected from every epidemic. The reason is that when Ida Ratu Gede Macaling leaves Nusa Penida for Bali, he is followed by a great number of followers. As He is believed to control every obstruction (Wighaniswara) both positive and negative things arise. The negative things can be in the forms of diseases, natural disasters, and environmental condition when it seems to rain but it is hot. The ritual is performed to neutralize that. (The interviewee: I Wayan Gede Upadana, 22 February 2019).

The information obtained through the interview above shows how the belief and the two dimensional dual viewpoints are related to each other. The ritual performed by the Balinese people functions as a balancing medium. It is performed due to the existence of Ida Ratu Gede Mas Macaling Dalem Nusa Penida. In relation to the existence of Ida Ratu Gede Mas Macaling Dalem Nusa Penida, it can be stated, therefore, that the mystical paradigm contributes to the pattern of the ritual performed by the Balinese people and the pattern of their habit.

The interview above also shows the same point of view. The invisible dimension cannot be separated from the visible dimension. The existence of Ida Ratu Gede Mas Macaling Dalem Nusa Penida is more viewed from the mystical aspect and this affects the Balinese people's pattern of behavior, as can be seen from the following information obtained from the following interview:

"Bentuk dari Barong Landung itu sebenarnya adalah dari perwujudan Ratu Gede Mas Macaling yang ada di Pura Dalem Peed Nusa Penida. Kisah itu sudah dituturkan sejak saya kecil sampai sekarang, dan saya sangat meyakini hal itu. Makanya masyarakat Bali sekarang memiliki bentuk Barong landung”. (Wawancara: Arya Pradipta, 9 February 2019)

The free translation is as follows:

Actually, Barong Landung shows what Ratu Gede Mas Macaling who is believed to reside at Dalem Peed 
Temple, Nusa Penida, is like. This has been narrated since I was a child until now, and I strongly believe in his existence. Therefore, the Balinese people still have Barong Landung in their temples (the interviewee: Arya Pradipta, 9 February 2019).

The information obtained through the interview above shows an invisible paradigm 'niskala', which is then believed to be true. One of the Balinese cultural products is what is referred to as barong landung. From another point of view, it symbolizes the unification of the Balinese culture and Chinese culture. However, the Balinese people also believe that barong landung represents what Ida Ratu Gede Mas Macaling Dalem Nusa Penida is like. This type of belief is based on invisible events.

The belief in and view point of what is invisible cause the cultural product to be defined widely. As a result, there are a number of people who state that the existence of Ida Ratu Gede Mas Macaling Dalem Nusa Penida is also responsible for the climate change, as can be seen from the following information obtained through another interview:

"Kalo sasih kapat (bulan keempat dalam perhitungan kalender Bali), suasananya masih segar. Bungabunga pada mekar dan berbau harum, cuara cerah dan ketika tiba masuk sasih kanem (bulan keenam dalam perhintingan kalender Bali), maka ada musim pancaroba. Di sinilah banyak sekali penyakit yang ada. Ada keyakinan yang saya sendiri begitu percaya, penyakit bisa muncul, ketika ada banyak sekali tempat yang tidak ada tapakannya (wujud bentuk seperti Barong). Maka dalam sasih inilah maka masyarakat memohon kesalamatan kehadapan Ida Bhatara Rau Gede Macaling agar berkenan memberikan kesalamatan. Sehingga musim yang buruk ini bisa berubah menjadi kehidupan bagi masyarakat Bali" (Wawancara: Dewa Putu Banjar, 20 February 2019).

The free translation is as follows.

"In the fourth season (the fourth month of the Balinese calendar), the atmosphere is still fresh. The flowers blossom and smell fragrant; the weather is bright; however, when sasih kanem (the sixth month of the Balinese calendar) starts, the weather changes, causing different diseases to appear where the barong 'tapakan' symbolizing the existence of Ida Bhatara Ratu Gede Macaling is not made to be available. Therefore, it is in this month we propose that he save and protect us; as a result, this bad season may change into a life for the Balinese people" (the interviewee: Dewa Putu Banjar, 20 February 2019).

The information obtained from the interview above shows that the Balinese people strongly believe in the existence of Ida Ratu Gede Mas Macaling Dalem Nusa Penida. The essence is that the transitional season which causes different types of viruses to appear can be neutralized by the existence of Ida Ratu Gede Mas Macaling Dalem Nusa Penida. What happens in the material world may result from what is invisible (niskala). Therefore, the paradigm adhered to by the Balinese people has two directions; they are sekala (visible) and niskala (invisible), and the connectedness of the discourse of Ida Ratu Gede Mas Macaling Dalem Nusa Penida to such a paradigm is getting stronger. The cultural products such as barong, rituals and several traditions performed in Bali are also inspired by the belief in the existence of Ida Ratu Gede Mas Macaling Dalem Nusa Penida, meaning that the connectedness of the discourse of Ida Ratu Gede Mas Macaling Dalem Nusa Penida results from different ritualistic traditions performed by the 
Balinese people. Therefore, the discourse of Ida Ratu Gede Mas Macaling Dalem Nusa is a great narration, in so far as the world of phenomena in the Balinese people's social environment is concerned, strengthens the belief of the Balinese people in what is visible as well in what is invisible 'sekalaniskala'.

The discourse functions to show that the Balinese people still believe that the invisible world cannot be separated from the physical (visible) 'sekala' world. The physical or immanent world will never be in existence without the transcendent or invisible 'sekala' world. This shows that the source of the material 'sekala' (visible) life is the invisible 'niskala' life, that the discourse of Ida Ratu Gede represents a message with the theme 'niskala' (invisibility) , and that the Balinese people treat what is invisible as something which is sacred. This is supported by the theory of reality proposed by Marcea Eliade (in Pals, 2008: 46), who explains that, actually, human life is made up of two aspects; they are the sacred aspect and the propane aspect. Everything which is extraordinary, invisible, and holy belongs to the sacred aspect, and everything which is common in daily life is under the propane aspect.

The discourse described above proves that what is invisible cannot be separated from human life. The Hindu religious practices performed in Bali and what is visible and what is invisible are the concepts leading to balance. The discourse of Ida Ratu Gede Mas Mecaling balances out the 'sekala' (visible) dimension. As well, the discourse can be used as a means of introspection 'mulat sarira' that life cannot be separated from two dual qualities 'Rwabhineda' (bad and good qualities). The discourse of Ida Ratu Gede Mas Mecaling clearly shows that what is played by what is invisible 'niskala' can be used as a solution to every life problem, as can be seen in the tradition of panyomnyan, which is performed in the sixth month 'sasih keenem' of the Balinese calendar in which the invisible strength is made to be present to neutralize every type of epidemic 'merana'. Based on this concept, 'niskala' (invisibility) is an important thing towards which the life of the Balinese people is oriented through which what is sacred is differentiated from what is propane. The concept of 'sekala-niskala' also represents two sides of the Balinese belief, namely what is referred to as Rwa Bhineda (1999:12), which refers to something with two dual aspects which are related to each other.

\section{Reflection of the Kawisesan Teaching in Bali}

The Kawisesan teaching is a teaching through which what is referred to as 'siddha' (the supernatural power) can be achieved. It can be achieved through several disciplines and prohibitions. Rituals are also performed to achieve the spiritual strength and the intuitional sharpness, and the highest achievement of the kawisesan is the unification of the soul (the human individual soul) with the Almighty God 'Paramatma').

The word kawisesaan is derived from "wisesa", meaning strength, supernatural, endeavor, extraordinary strength (Darmika, 2011:126). Based on the definition that kawisesaan means strength, the kawiseaan teaching means a teaching which can make those who learn it able to have supernatural power, meaning that the power they have exceeds that which common human beings have if viewed from the metaphysic dimension.

Actually, the metaphysic strength can move and go to the metaphysic scope, meaning that whatever happens resulting from any physical fact can affect the human physical aspects. The discourse of Ida Ratu Gede Mas Macaling Dalem Nusa Penida gives many kawisesan-related teachings which are still performed and develop in the Balinese community. In the discourse it is stated that before he is named Ida Ratu Gede Mas Macaling Dalem Nusa Penida, he was named I Gede Macaling.

I Gede Macaling mediated in Peed and worshipped Lord Siwa. The descipline 'tapa' was consciously performed to control 
his words, thoughts and actions. As he could perfectly meditate and reach the highest level, Lord Siwa did not mind appearing before him and awarded what is referred to as Kanda Singa to him. When Kanda Singa was awarded to him, his body became so big, his tusks became long, and he looked frightening (Paramitha, 2018).

What he was like totally changed and was frightening. His voice thundered throughout the universe. His tusks was getting longer, which, in the Balinese tradition, are referred to as caling. They are awarded by Lord Siwa, and the other gods were not able to defeat him.

The discourse above subversively affirmed the kawisesan teaching in Bali. One can acquire kawisesan if one can acquire the strength of siddha, which is the strength which is not possessed by common people, and can control one's self. Self-control 'tapa' performed by I Gede Macaling, is the initial step of every discipline of the kawisesan teaching. The reason is that it would be highly difficult to practice it without discipline. Tapa, self-control, as the basic step in the Kawisesan teaching, can be performed through the following disciplines.

1. Monabrata. This discipline refers to the activity in which those who perform it do not converse with others. This is usually performed by not uttering any word.

2. Upavasa. This discipline refers to the activity in which those who perform it neither drink nor eat anything during a particular period of time.

3. Sauca. This discipline refers to the activity in which those who perform it purify themselves by bathing and through a ritual referred to as prayascitta, which is performed by proposing for holy water for purifying themselves.

These disciplines should be performed well and correctly before getting involved in spiritual exercises. Many people become interested in the knowledge of kawisesan but they fail to perform the disciplines prescribed above. It is important for those who are interested in it to perform and understand the disciplines before they are supposed to acquire the other steps required in the supernatural scope.

\section{a) Rudra Murti Kawisesan}

Several people become interested in acquiring kawisesan follow the activity of 'tapa' as what was done by I Gede Macaling, as they would like to become other Ida Ratu Gede Mas Macalings. They mainly concentrate on Lord Siwa, who is also referred to as Lord Rudra. Those who become interested in kawisesan teaching believe in the discourse that Ida Ratu Gede Mas Macaling was awarded with supernatural power by Lord Rudra for the second time he performed the activity of tapa.

\section{b) Kanda Sanga}

The kewisesan teaching which the myth of Ida Ratu Gede Mecaling Dalem Nusa Penida contains is Kanda Sanga. It is narrated that I Renggan who was married to Ni Merahim had one boy and one girl. The boy's name was I Gede Macaling and he became Ida Ratu Gede Mas Macaling Dalem Nusa Penita and the girl's name was $\mathrm{Ni}$ Tole. In 230 Saka year, I Gede Macaling meditated at Peed and his prayers were addressed to Lord Siwa (Adnyana, 2009:9).

During the process of tapa (selfcontrol), he fully concentrated his mind on Lord Siwa, who then did not mind descending and awarding Kanda Sanga to him. Literally, the word "kanda" means showing several parts and dimensions and even a teaching as a whole. The word "sangga" means nine; however, if it is pronounced "sangga", it will mean a "collection". The word sanga, which means nine, means the realization of self-strength with "nine doors".

The expression "nine doors" refers to the human body itself. The human body has nine doors; they are the mouth, two eyes, two ears, one nose, one anus, one sex organ and the fontanel known as Siwadwara. It is stated that the fontanel is identical with the name Siwadwara, which literally means being divided into two. 


\section{Conclusion}

Based on what was described above, it can be concluded that the existence of the myth of Ida Ratu Gede Mas Macaling Dalem Nusa cannot be separated from the Bahirawa Tantra teaching in Bali. Actually, it represents the Bhairawa teaching which semantically explains the unification of Bhairawa-Bhairawi as the mystical unification of Siwa-Sakti. The myth cannot be separated from the belief in sekala-niskala (what is visible and what is invisible) in the life of the Balinese society and the role played by the kawisesan teaching in Bali.

\section{References}

Acri, Andrea. 2018. Dharma Patanjala Kitab Saiwa dari Jawa Zaman Kuno. Jakarta: KPG (Kepustakaan Kompas Gramedia).

Adnyana, I Gede Agus Budi. 2009. Orang Terpelajar yang Bodoh. Denpasar: Pustaka Bali Pos.

Atmaja, Jiwa. 2017. Jejak Bhairawa di Pulau Bali. Denpasar: Udayana University Press.

Darmika, I Wayan, 2011. Mitos Ida Ratu Gede Dalem Nusa (Artikel Taksu, 2011). Denpasar: Taksu.

Kardji, Nyoman. 1999. Rwa Bhineda. Denpasar: Sari Kahyangan.

Pals, Deniels. 2008. Seven Theory of Relegion. Jogjakarta: Pustaka Pelajar.

Paramitha, N. M. A. S. P. (2018). Theological Symbolisation Of Watugunung Myth And Sangkuriang Legend (Comparative Literature Study). Vidyottama Sanatana: International Journal of Hindu Science and Religious Studies, 2(2), 211-217.

Putrawan, Nyoman. 2008. Mitos dan Kebenaran Ida Ratu Gede. Denpasar: Manik Geni.

Redig, I Ketut. 2009. Jejak Tantrayana di Bali. Denpasar: Udayana University Press.
Suastika, I. M., Jirnaya, I. K., Sukersa, I. W., \& Puspawati, L. P. (2017). The Process Of Transforming The Mahabharata Literary Work Written In The Old Javanese Into Geguritan Sarpayajnya And Geguritan Kicaka Written In The Balinese Language. Vidyottama Sanatana: International Journal of Hindu Science and Religious Studies, 1(2), 103-114.

Sukayasa, I Wayan. 2010. Rasa dalam Geguritan Sucita Subudi. Denpasar: Pustaka Larasan.

Sutrisno. Nanang. 2005. Keberadaan Mitos Ida Ratu Gede Mas Macaling. Denpasar: Pustaka Larasan. 